\title{
Climate Change in the Capital Markets: A Study of Actively Managed Green Bond Funds*
}

\author{
Emilia Németh-Durkó - Anita Hegedüs
}

In this study, we carried out a performance analysis of green bond portfolios available from public databases for the period between 2017 and 2020. The aim of our research was to obtain empirical proof for the existence of the green premium, which was confirmed by risk-adjusted indicators, i.e. the Sharpe ratio, the $M^{2}$ ratio and the Sortino ratio. The green premium is the return differential that can be measured between green and conventional financial instruments. According to the literature, investors are willing to forego 1 to 9 basis points of their returns in the interests of financing climate targets, to cover the issuer's extra costs incurred from green bond ratings and reporting obligations. Our results confirmed that the green bond portfolio underperforms benchmark indices by an average green premium of 2 basis points. We only found a single green bond fund that did not involve a green premium and was capable of achieving a risk-adjusted excess return. Nevertheless, it is noted that all of the indicators used showed that the average performance of green bonds improved steadily each year in the period under review.

Journal of Economic Literature (JEL) codes: C5, G10, G31, G38, Q50

Keywords: sustainable investments, climate finance, green bonds, portfolio analysis

\section{Introduction}

In spring 2021, a green government bond with the longest maturity in the world made its debut in Hungary. The auction attracted huge investor interest, generating demand several times higher the planned volume to be sold. Targeted at fund managers pursuing sustainable investments, the 30-year, fixed-rate government bond is, according to Bloomberg, unprecedented in green capital markets. The

\footnotetext{
* The papers in this issue contain the views of the authors which are not necessarily the same as the official views of the Magyar Nemzeti Bank.

Emilia Németh-Durkó is an Assistant Lecturer at the Corvinus University of Budapest.

E-mail:emilia.durko@uni-corvinus.hu

Anita Hegedüs is a Recipient of the Thesis Award from the Hungarian Society of Economics, and an Undergraduate Student in finance and accounting at the Corvinus University of Budapest.

Email: hegedus.anita96@gmail.com
}

For Emilia Németh-Durkó, this research was supported by the Higher Education Institutional Excellence Program 2020 of the Ministry of Innovation and Technology in the framework of the 'Financial and Public Services' research project (TKP2020-IKA-02) at Corvinus University of Budapest.

The Hungarian manuscript was received on 22 June 2021.

DOI: http://doi.org/10.33893/FER.20.4.3864 
HUF-denominated green bonds were issued in a volume 1.5 times that originally foreseen. ${ }^{1}$ In raising funds for environmental and sustainable climate objectives, Hungary is not only present in the government bond market, but is also represented by the green bonds of several companies operating in Hungary, and many potential institutional investors are planning further expansion of green portfolios. ${ }^{2}$

The rapid spread of green bonds and the growing interest in sustainable investments are not specific to Hungary. In recent years, the issue of global warming has been playing an increasingly important role in corporate social responsibility and in managing banks' climate risks. For sustainable economic growth and development, fiscal and structural reforms are needed to reduce emissions to the atmosphere. According to an estimate by the OECD (2017), infrastructure developments to slow global warming is estimated to USD 6.9 trillion annually over the next 15 years. Government resources, especially in developing countries, are not sufficient to manage the climate problem (Reichelt 2010). Banks are facing a challenge in financing projects designed to support the spread of long-term renewable energy solutions and low-carbon projects (Boros 2020), and businesses in facilitating decarbonisation processes (Fogarassy et al. 2018).

The spread of green portfolios in capital markets is one possible way of financing the mitigation of climate change and damage from global warming. There are investors who are willing to forego part of their returns for the sake of environmental objectives and pay a green premium ("greenium") to that end (Zerbib et al. 2019; Baker et al. 2018; Ehlers - Packer 2017). However, green bonds can not only provide an alternative for investors committed to environmental protection, but also have a number of advantages over conventional bond portfolios in capital markets. According to some studies, the returns on green bond portfolios exceed those achieved by conventional bonds (Karpf-Mandell 2018), and even in difficult economic circumstances, such as the Covid-19 period of the past year, they have proved to be crisis-proof investments (Taghizadeh-Hesary et al. 2021).

In our study, we focus on a portfolio analysis to describe the conceptual structure and market for green bonds. In addition to explaining the specific features of the market, we also highlight regulatory problems and the difficulties faced by the sector, for example the phenomenon of greenwashing, i.e. making companies appear more sustainable. In our empirical research, we examine the financial performance of actively managed green bond funds in a public-database portfolio.

${ }^{1}$ ÁKK issued a 30-year Green Hungarian Government Bond on Earth Day. https://akk.hu/ download?path=21c8a460-03fe-431d-8907-50796766fd01.pdf. Downloaded: 20 May 2021.

${ }^{2}$ A kulisszák mögött: így zajlik a vállalatoknál a zöld kötvények kibocsátása (Behind the Scenes: How Corporates Issue Green Bonds). https://www.hugbc.hu/hirek/a-kulisszak-mogott-igy-zajlik-a-vallalatoknala-zold-kotvenyek-kibocsatasa/4262. Downloaded: 20 September 2021. 
Our research question is whether the green premium exists, i.e. whether the returns on green bond funds are significantly lower than that of the conventional bond portfolio. Our research is a contribution to the growing body of literature on green investments, which have been attracting increasing interest, whereas in the context of Hungarian empirical analyses, our inquiry into the financial performance of green bond funds fills a gap by virtue of its focus and the limited number of such analyses.

Our study is structured as follows: Section 2 presents the market for green bonds and the geographical and other characteristics of bond issues. Section 3 describes the institutional conditions and the regulatory framework, while Section 4 focuses on the results of empirical research through an account of studies on the existence of the green premium. Section 5 reports on our own research, with a summary of our conclusions provided in Section 6.

\section{Green bonds in the capital markets}

While sustainable investment is an established concept in the equity market, ${ }^{3}$ the concept of green bonds is a relatively new element. In this Section, we first discuss how green bonds are issued and the role they play in the market, and subsequently provide an inventory of regulatory problems.

\subsection{The uptake of green bonds in markets}

The most fundamental difference between green bonds and conventional bonds is that the income from green bonds is used to finance environmentally friendly projects (Pham 2016). The aggregate net asset value of green bond funds and green bond ETFs is growing dynamically. The global green bond market has expanded rapidly since the launch of the climate awareness bond in 2007, and in 2018 the global issue of labelled green bonds reached USD 167 billion, although it still accounts for only a few per cent of the global bond market today (Hyun et al. 2019). The expansion affected capital markets differently, and green bonds represent a constantly changing segment both geographically and from an issuer perspective.

The first green bond, known as the "climate awareness" bond, was issued by the supranational European Investment Bank in the approximate amount of EUR 600 million. The first entrant to the market in the public sector was the Norwegian Kommunalbanken in 2010, while the first sovereign issuer was Poland, but only in 2016 (Filkova et al. 2018). With the volume and value of issues increasing each year, Figure 1 shows a green bond market boom in almost all regions. Europe has been in the lead for the period, also acting as the main nexus of the upswing in

\footnotetext{
${ }^{3}$ Sustainable investment refers to the emergence of environmental, social \& governance (ESG) factors in the capital market. The focus of this research is limited to a description of the green bond market.
} 
2018-2019, recording a growth rate of 79 per cent to reach a market size of USD 117 billion, with European issues accounting for half the total market ( $C B / 2020)$. Jókuthy (2020) points out that the market dynamics are well illustrated by the temporal concentration of global green bond issues within recent years. Today, countries that were previously less focused on sustainability aspects, or were even considered exotic, such as Russia, Ukraine or Kenya, have also emerged as issuers.

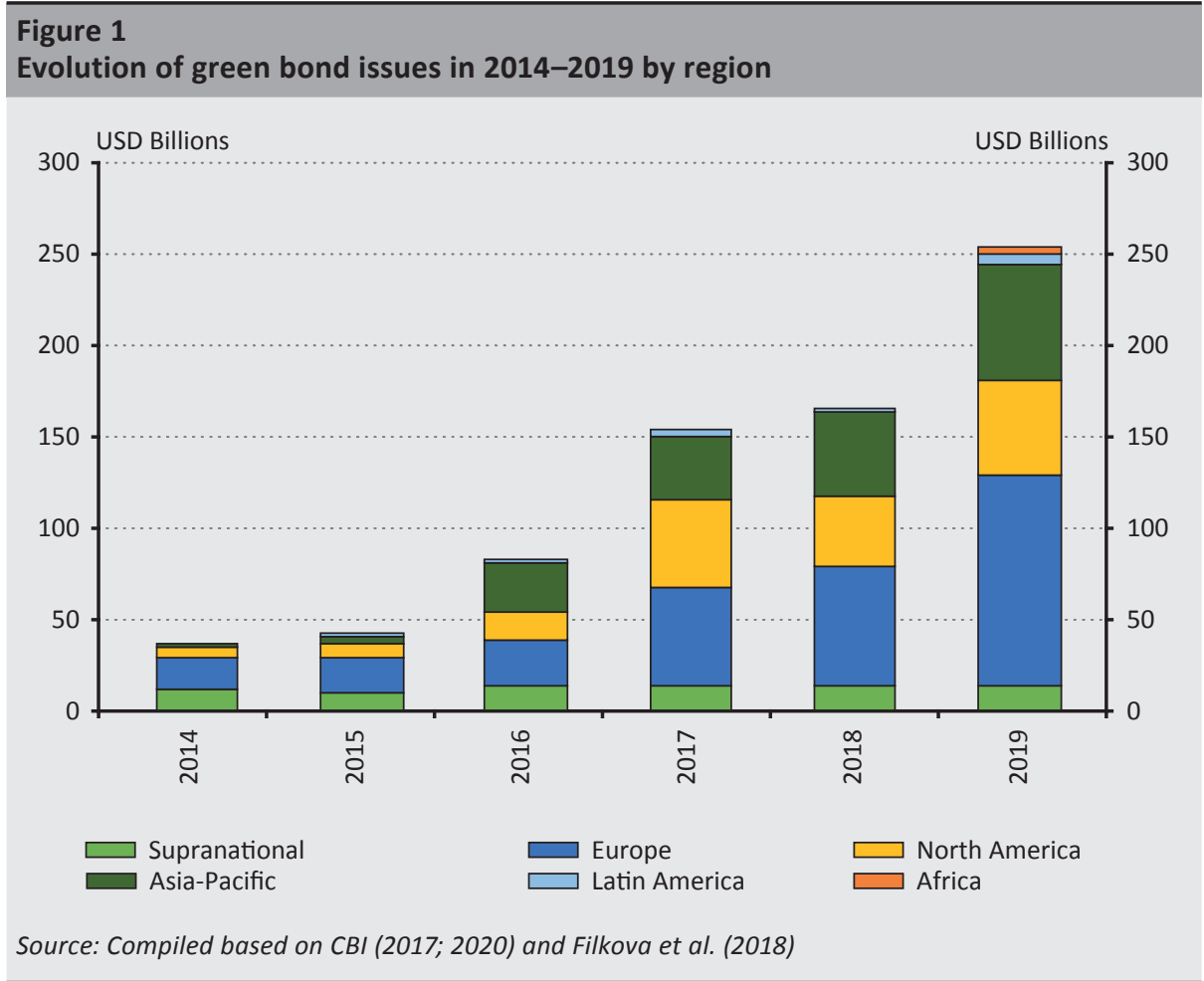

The financial resources obtained via green bonds serve a wide variety of purposes within green objectives, as they can be used both to prevent climate change and mitigate its consequences, also referred to as mitigation objectives. Green energy developments are among the most typical investment objectives, but the improvement of water and wastewater management, transport and energy efficiency are also popular financing objectives. Almost half of the funds raised are spent on green energy development (47 per cent), and combined with the greening of buildings ( 22 per cent), these two priorities account for two-thirds of utilisation. Energy efficiency ( 8 per cent) and transport ( 9 per cent) receive the smallest shares of green funds (ICMA 2019; MNB 2019). 
Despite its rapid expansion, the green bond market is still very small compared to the global bond market, accounting for about 2 per cent of bonds issued globally (Ehlers - Packer 2017). The main obstacle to the development of the market is probably the universal lack of a definition for green bonds and of generally recognised standards. Ethical investors associate investments in green bonds with positive environmental impacts, but without generally recognised green bond standards, it is difficult for investors to identify whether green bonds are in fact green. This may stem from the fact that the purpose for which the funds are to be used is less specifically stated when a green bond is defined in general, while it would also be appropriate to precisely define and document the utilisation of funds for green objectives, along with supporting processes (MNB 2019).

\subsection{Standards and regulatory problems}

The definition delimiting the concept of green bonds is used consistently in the literature. Revenue from green bonds can only be used to finance environmentally friendly projects (Pham 2016) or only for investments that generate some kind of direct or indirect benefit for environmental or climate protection (Mihálovits Tapaszti 2018). In other terms, a green bond is also defined as a hybrid financial instrument that combines the environmental benefits with the features of conventional fixed-rate instruments to channel funds to environmentally friendly projects (Hyun et al. 2019). In its summary, the MNB (2019) underlines the role of the issuer, which must responsibly undertake to "use the funds raised from the bonds to finance some environmental or related investment".

While the definition builds on similar elements, there is less transparency and harmony as regards the regulatory system, engagements and purposes for which the funds can be utilised. The literature (IBA 2021; Mihálovits - Tapaszti 2018; Kolozsi 2019) consistently calls for uniform regulatory and rating standards. Several green bond issuers have developed proprietary green bond frameworks. Development banks such as the Asian Development Bank and the International Finance Corporation, as well as other players such as the Nordic Investment Bank, have declared market regulation mechanisms (Deschryver - de Mariz 2020), but many questions remain unanswered, even according to the latest literature.

Initiatives supported by public or private entities in this sector have only established "recommendations" and "guidelines", which can be adopted on a voluntary basis. The Green Bond Principles (GBP) developed by the International Capital Markets Association (ICMA) are the most important voluntary guidelines for the issuance of green bonds (IBA 2021). The European Union is currently in the process of developing a framework for green finance. The first step was taken in March 2018, when the European Commission adopted a comprehensive plan to promote sustainable financing (the Sustainable Finance Action Plan) and set up its Technical 
Expert Group on Sustainable Finance, which drew up the first draft of the EU Green Bond Standard.

As green bonds are an instrument aimed at eliminating the negative effects of economic activity on the environment and may even promise extra returns for investors, green bonds very soon received considerable attention worldwide. Mihálovits - Tapaszti (2018) collected the challenges lying ahead of the green bond market and also offered solutions to the problems listed (Figure 2). The regulatory system has been less successful in keeping abreast with the steady increase in interest and capital market prominence; a uniform regulatory framework for both investors and issuers, and market transparency have proven deficient in connection with the issuance of green bonds. The clarification of uniform international standards and responsibilities would resolve the uncertainties surrounding the rating of green bonds, but at least as much emphasis should be placed on the development of a quantitative scaling system to provide investors with feedback on financing outcomes.

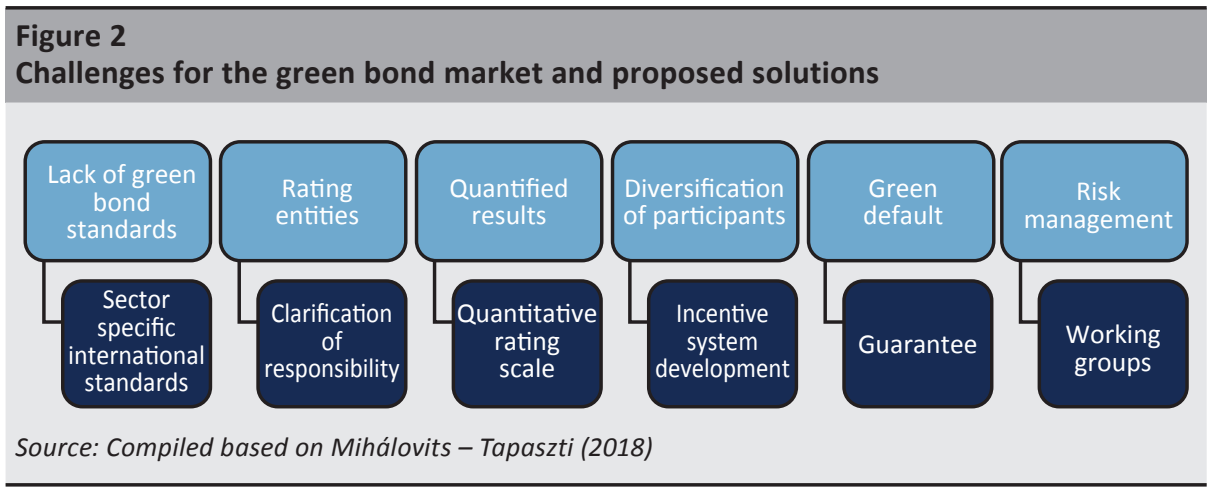

Apart from the uniformity of precise regulation, criticism is also justified for the hard-to-define green criterion, which determines the purpose of finance. What makes an investment green? Does improved energy efficiency in a coal plant support sustainable principles? Are areas that do not serve climate objectives, but suffer the consequences of climate change eligible? By asking such questions, Gyura (2019) points out the need for some definition of environmental utility in order to maintain confidence in the green bond market. Failing that, promoting sustainable values in capital markets could trigger the opposite effect.

Due to a regulatory framework that allows flexibility in interpretation, companies may become inclined to give the impression that they are "greener" than the green benefits they actually possess. Since the environmental utility of such companies can be questioned according to several studies (Kidd 2015; Shislov et al. 2016; Gyura 2019), greenwashing could bring the emerging segment of green-labelled financial instruments to an abrupt halt by destroying investor confidence. Timár 
(2021) argues that the fact that he found no significantly abnormal returns in the pricing of responsible and sustainable investments with companies listed on the New York Stock Exchange could be attributed to the phenomenon of greenwashing.

The green bond market, as we have seen, continues to face many uncertainties and challenges on the regulatory front. While climate risks and the role of banks will not be addressed in this study, a paper by Baranyai - Banai (2020) does show that the banking sector is also involved in climate risk management. Arrangements for the establishment and review of uniform principles are one of the most urgent issues and, given the need for a reallocation of capital due to decarbonisation and the transition to a carbon-neutral economy (Kolozsi 2019; Fogarassy et al. 2018), risk management must be transformed and sustainability must become an integral part of investment decisions. On the other hand, green bonds must be in line with the issuer's climate strategy, making it absolutely necessary to examine the issuer's commitment so that greenwashing is contained. ${ }^{4}$

\section{Pricing specificities of green bonds - the green premium}

Today, sustainable investment is a quickly growing area of scientific research, with a body of literature that is expanding at a tremendous rate every year (NémethDurkó 2019). There has been a dynamic increase in the emphasis and measurement of the role of corporate, social and environmental aspects in the banking and capital markets. Such areas include calculations of returns, green premiums and, with at least as much interest, the risks of sustainable investments. In this Section, we present the specific features involved in the pricing mechanism of green bonds and examine the green premium with reference to the return differentials as measured in the literature.

Issuers of green bonds may incur additional costs from certifying the compliance of their bonds with the relevant directives, keeping the revenues in separate accounts, specifying the internal processes required for the selection of eligible projects and reporting regularly on the use and impact of revenues, which will compel them to enter the market at a higher price and with lower returns compared to conventional bonds. The return differential resulting from this mechanism is referred to as the green premium. The cost of issuing green bonds ranges from 0.3 to 0.6 basis points for an issue of USD 500 million (Hachenberg - Schiereck 2018) and this represents a particular challenge for smaller issuers (Forsbacka - Vulturius 2019; Tuhkanen Vulturius 2020; Sartzetakis 2020).

\footnotetext{
${ }^{4}$ Tapaszti, A.: ESG- és zöldbefektetések a jegybanki portfóliómenedzsmentben (ESG and green investments in central bank portfolio management) https://economaniablog.hu/2021/04/09/esg-es-zoldbefekteteseka-jegybanki-portfoliomenedzsmentben/. Downloaded: 10 June 2021.
} 
The body of literature on the green premium comprises a rather small number of empirical works. MacAskill et al. (2021), in their summary of green bond performance and the green premium, report only 15 studies on bond issues in primary and secondary markets between 2007 and 2019. The consensus on the existence of a green premium is confirmed by their research for more than half of the green bonds, in particular green bonds that are sovereign-issued and comply with the standards and reporting obligations that can be expected from green bonds. The authors estimate the size of the green premium within a range of 1 to 9 basis points on average, indicating the average share of the returns that investors are willing to forego in favour of financing environmental objectives. In other words, investors pay a (negative) price premium on green bonds, i.e. they tolerate lower returns on green bonds compared to conventional bonds. Tuhkanen and Vulturius (2020) argue that the green premium benefits issuers and reduces their financial costs of issuing.

The premium on green bonds can be present in both the primary and secondary markets. In the primary market, where new bond issues are offered to investors, these issuance costs would translate into a higher price for a green bond compared to a conventional bond. Once the bonds have been issued, in the secondary market they are traded freely and subject to price movements. The presence of a negative green premium in primary or secondary markets means that a green bond trades at a lower return (or higher price) compared to a conventional bond with similar characteristics. "By placing green bonds on the market, issuers credibly indicate their commitment to protecting, maintaining or restoring the environment. As a result of investor interest generated by the related benefits, issuers are generally able to price green (and third-party certified) bonds at a premium" (Sági 2020). By purchasing bonds that offer lower returns but are green, investors reward the issuer with lower financing costs for the implementation of projects targeting environmental measures.

The literature shows that the existence of the green premium is empirically confirmed by a major part of the studies (Table 1). For different periods and a variety of markets, similar conclusions were reached. Investors are willing to forego a part of their returns by buying green bonds. In other words, they are willing to pay a premium for climate finance. Based on the works covered by our review, the green premium was found to be a minimum of -0.17 basis point and a maximum of -63.2 basis points compared to the returns on conventional bonds.

The lowest green premium is reported by Harrison (2019). Regarding the performance of American and European green bonds, on a sample of 61 green bonds, she found the return on green bonds to be 0.17 basis point lower compared to conventional bonds. On a global sample, but comprising a smaller universe of green bonds, a much higher green premium ( -63.2 basis points) is reported by 
Nanayakkara - Colombage (2019), who compared bond performance for the period 2016-2017. Zerbib (2019) also analyses a portfolio compiled from the global market, with one-tenth of his original sample eventually included in the model due to the strict criteria of the matching methodology and their fulfilment. Matching each green bond with a conventional bond with comparable properties, he found the return on green bonds to be 1.8 basis points lower in the period 2013-2017. This premium in return for achieving environmental objectives is, according to the author, not significant and is not expected to discourage investors from investing in green bonds.

\begin{tabular}{|c|c|c|c|c|c|c|}
\hline \multicolumn{7}{|l|}{$\begin{array}{l}\text { Table } 1 \\
\text { Results } \mathrm{f}\end{array}$} \\
\hline Author & Year & $\begin{array}{l}\text { Market/ } \\
\text { Dimension }\end{array}$ & Method* & Period & $\begin{array}{l}\text { Green bonds } \\
\text { (pcs) }\end{array}$ & $\begin{array}{c}\text { Green } \\
\text { premium } \\
\text { (basis } \\
\text { points) }\end{array}$ \\
\hline $\begin{array}{l}\text { Ehlers and } \\
\text { Packer }\end{array}$ & 2017 & $\begin{array}{l}\text { USA and } \\
\text { Germany }\end{array}$ & Matching & 2007-2014 & 21 & -18 \\
\hline Bauer et al. & 2018 & $\begin{array}{c}\text { USA (local } \\
\text { governments) }\end{array}$ & CAPM & 2014-2016 & 2,083 & -6 \\
\hline Bauer et al. & 2018 & $\begin{array}{c}\text { USA } \\
\text { (corporate) }\end{array}$ & CAPM & 2014-2016 & 19 & - \\
\hline Tang and Zhang & 2018 & global & OLS & 2007-2017 & 665 & - \\
\hline Hyun et al. & 2018 & global & Matching & 2010-2017 & 60 & - \\
\hline Zerbib et al. & 2019 & global & Matching & 2013-2017 & 110 & -1.8 \\
\hline $\begin{array}{l}\text { Nanayakkara } \\
\text { and Colombage }\end{array}$ & 2019 & global & OLS & 2016-2017 & 43 & -63.2 \\
\hline Harrison & 2019 & EU and USA & OLS & 2019 & 61 & -0.17 \\
\hline $\begin{array}{l}\text { Gianfrate and } \\
\text { Peri }\end{array}$ & 2019 & EU & Matching, OLS & 2013-2017 & 121 & -0.2 \\
\hline $\begin{array}{l}\text { Karpf and } \\
\text { Mandel }\end{array}$ & 2018 & $\begin{array}{c}\text { USA (local } \\
\text { governments) }\end{array}$ & $\begin{array}{l}\text { Oaxaca-Blinder } \\
\text { decomposition }\end{array}$ & 2010-2016 & 1,880 & +7.8 \\
\hline
\end{tabular}

Note: * CAPM - capital asset pricing model, OLS - ordinary least squares.

The existence of the green premium has been disproved by a small number of studies (Baker et al. 2018; Tang - Zhang, 2018; Hyun et al. 2018) on the grounds that no significant difference was demonstrated between the returns on green and conventional bonds. Tang - Zhang (2018) found no significant premium or discount for green bonds that was constant in time, but established a significant positive response in stock prices to corporate green bond issues. The issue of green bonds brought about a significant improvement in the liquidity of the shares, implying that a corporate decision on the issue of green bonds promises to be beneficial for shareholders at the time. Although in contrast with the work of Tang - Zhang (2018), Hyun et al. (2018) report a green premium in the range of 6-9 basis points, 
they note that this only applies to green bonds rated externally by Climate Bonds Initiative (CBI) or another entity. Carried out between 2010 and 2017, their research is based on a sample of 60 green bonds denominated in GBP versus conventional bonds with comparable properties, in alignment with the research methodology of Zerbib (2019).

The classification of green bond issuers, i.e. corporate and municipal, is also subject to analysis. Partridge - Medda (2020) report on better performing green indices. The Municipal Green Bond Index outperformed the nearest equivalent S\&P index between 2014 and 2018. In their research, Karpf - Mandel (2018) also reported superior performance by green bonds: controlled for the liquidity of green bonds from a database of about 2,000 items, a green premium of +7.8 basis points was obtained over a 30-day horizon. In contrast with most research, in this case the premium is a positive value, suggesting that the green bonds issued by local governments are perceived as less risky by the market and investors.

In terms of methodology, risk-adjusted ratios are a popular means of analysing the performance of investment funds, and that approach is taken into account for both bonds and equity portfolios. In their comparative analysis of 131 green funds against risk-adjusted ratios, Chen - Chang (2012) found green funds to have outperformed the peer group consisting of conventional funds. Using an extended version of the Fama and French 3-factor model, the financial performance of conventional funds was found to have been better than that of green funds, while there was no significant difference between the risk-adjusted performances of green and black portfolios. Consistent with the conclusion of Chen - Chang (2012), based on an analysis of 175 green funds, 259 black funds and 976 conventional funds, it was found that when the time window was moved forward, the green funds achieved increasingly higher returns between 2012 and 2014, with the green premium disappearing (Ibikunle - Steffen 2017).

Our literature review confirms the empirical evidence for the existence of a green premium. Most research papers agree on a significant confirmation of a green premium, i.e. negative returns on green bonds. Assertions to the contrary are made in very few studies. In the following we present the results of our own research.

\section{The green bond portfolio and methods to measure performance}

In our research, we examine the performance of a portfolio of publicly available assets. We look for empirical evidence for the existence of a greenium by determining whether the performance of a green portfolio matches that of market benchmark indices or falls short of the market. Our results show whether green bonds offer a profitable investment alternative, or instead serve corporate reputational purposes, for which investors committed to sustainability are willing to pay (i.e. incur a loss of return). 
In our database, we collected actively managed funds, the purpose of which is to overperform their benchmark. Active fund management builds on the portfolio manager's ability to pick securities and to act on the market with appropriate timing and specific strategies, while the other type, passive fund management, operates by producing the returns of a market index as accurately as possible. We opted for actively managed funds on the grounds of an estimate, according to which 23 per cent of such funds outperformed their passive counterparts (Stempler 2021).

We use a variety of indicators for the assessment of green bond portfolios. To characterise market conditions from the CAPM model (for our purposes, the index model) we use alpha and beta, and to measure risk-adjusted performance, we use the Sharpe ratio, the $\mathrm{M}^{2}$ ratio and the Sortino ratio. One of our research hypotheses is that the average return on green bond funds is lower than the market benchmark return, i.e. a green premium exists. To report returns and performance in the most actual terms possible, we infer the answer to the hypothesis from the value of the risk-adjusted ratios. Our second hypothesis is that there are green bond funds in the case of which active fund management creates value and achieves higher returns than the market thanks to the ability of the fund manager. We answer the hypothesis based on the results for the alphas of the green bonds.

\subsection{Characteristics of the database examined}

Due to the relatively young market, the period considered in this study to analyse the performance of green bonds is from 1 March 2017 to 28 February 2020. Of the 32 green bond funds defined by Environmental Finance, which examined only those funds in which green bonds accounted for at least half of their weight, 17 met the three-year timeframe criterion, of which only 11 had historical data available. As in the research by Climent - Soriano (2011), our database only consists of openended, primary investment funds, which are freely available to any investor. The exclusive focus of the asset class is bonds. The data have been collected from four different database: Yahoo Finance, Boursorama, Markets and Umundi. The list, currency and net asset value of the green bond funds included in the analysis are shown in Table 2. 


\begin{tabular}{|c|c|c|}
\hline \multicolumn{3}{|c|}{$\begin{array}{l}\text { Table } 2 \\
\text { Main characteristics of the green bond funds examined in the research }\end{array}$} \\
\hline Name & Currency & Net asset value 2019 (million USD) \\
\hline Allianz Green Bond W EUR & EUR & 383.58 \\
\hline Amundi Rspnb Investing Green Bds I C & EUR & 86.79 \\
\hline Amundi Rspnb Investing Imp Gr Bds I C & EUR & 385.17 \\
\hline AXAWF Global Green Bds I Dis EUR & EUR & 251.82 \\
\hline BfS Nachhaltigkeitsfonds Green Bonds & EUR & 21.97 \\
\hline Calvert Green Bond I & USD & 418.39 \\
\hline JSS Sustainable Green Bd Glb P EUR acc & EUR & 24.36 \\
\hline Mirova Global Green Bond N & USD & 39.65 \\
\hline NN (L) Green Bond I Cap EUR & EUR & $1,422.64$ \\
\hline Raiffeisen-GreenBonds I T & EUR & 103.03 \\
\hline SEB Green Bond D EUR & EUR & 122.62 \\
\hline
\end{tabular}

The portfolio we constructed includes a total of 11 green bond funds. The total value of the assets managed in the funds is approximately USD 4,440 million. The cumulative net asset value of green bond funds represents less than half of the assets managed by the overall market during this period. All of the funds listed are open-ended, with nine denominated in EUR and two in USD. Although U.S. bonds have the greatest weight in USD funds and European bonds have the greatest weight in the EUR funds, they are not categorised separately in the analysis because each portfolio is diversified geographically and includes both corporate and government bonds. For the purpose of determining the return premium, we chose the return on the three-month U.S. Treasury Bill as the risk-free return, which is derived from the website of the U.S. Department of the Treasury.

An important part of the analysis is the selection of appropriate benchmark portfolios, as each index can significantly affect the return of bond funds. In the research, we worked with 3 indices, to which we compare the performance of the funds. The first index represents the green bond market (S\&P Green Bond Index), the second index (S\&P Global Developed Aggregate Ex-Collateralized Bond Index) represents the conventional bond market, and the third index ( $\mathrm{MSCl}$ All Country World Index) represents the global securities market. 
The three most popular green indices are the Bloomberg Barclays $\mathrm{MSCl}$ Green Bond Index, the Solactive Green Bond Index and the S\&P Green Bond Index, of which we chose the latter, since it is the most diversified of all, with the highest number of constituents. The S\&P Green Bond Index was designed to monitor the global green bond market. The pioneering index maintains strict standards in order to include only bonds, the income from which is used to finance environmentally friendly projects. One of the most commonly used benchmarks for global fixed-rate instruments is the S\&P Global Developed Aggregate Ex-Collateralized Bond Index, which tracks the performance of bonds issued by sovereigns, governments and market companies.

The third index against which the performance of green bond funds was measured is the $\mathrm{MSCl}$ All Country World Index. In most of the literature on the performance of investment funds, besides the FTSE All-World Index, it is used to represent the overall financial market. The $\mathrm{MSCl}$ All Country World Index is a global equity index designed to represent large and mid-caps in 23 developed and 26 emerging markets. In December 2019, it had more than 3,000 constituents in 11 different sectors.

\subsection{Methodology for the analysis of actively managed portfolios}

In the literature, the performance of actively managed portfolios is evaluated against a number of criteria, most frequently using risk-adjusted ratios such as the Jensen's alpha, the Sharpe ratio, the Sortino ratio and the $\mathrm{M}^{2}$ ratio (Rácz 2019). When calculating the green premium, most of the literature presented in our review compares the performance of the green portfolio with a conventional bond portfolio. In a different approach, this research looks for evidence for the existence of a green premium in relation to the performance of market (benchmark) indices (equity index, bond index, green bond index) focusing on three different asset classes.

The most commonly used metric for risk-adjusted returns and to compare investments is the Sharpe ratio, which shows the excess return per unit of risk, i.e. of standard deviation. It signifies the "attractiveness" of an investment, that is, whether the investment fund provides an adequate excess return for a unit of additional risk taken. Since the assessment of returns could provide a distorted view of an investment strategy due to differences in risk-taking, the risk-adjusted ratios ensure that assets bearing different risks are comparable. The Sharpe ratio is obtained using the following formula:

$$
\text { Sharpe ratio }=\left(r_{i}-r_{f}\right) / \sigma_{i}
$$

where $r_{i}$ is the return on the asset, $r_{f}$ is the risk-free return, and $\sigma_{i}$ is the standard deviation, i.e. risk, of the asset. The Sharpe ratio allows comparisons between the performance of the funds and that of its reference indices. A fund with a Sharpe 
ratio exceeding that of the indices is considered to have outperformed the indices. However, there are cases where the Sharpe ratio does not give reliable results, for example, where returns are associated with a negative skewness, it underestimates the risk, indicating a strategy that actually carries more risk than what is suggested by the Sharpe ratio, ${ }^{5}$ which calls for the use of additional ratios.

The Sortino ratio is an enhanced version of the Sharpe ratio that also measures risk-adjusted performance, with the difference that while the Sharpe ratio takes into account the overall standard deviation, the Sortino ratio only takes into account negative standard deviation, i.e., contrary to the Sharpe ratio, it ignores positive volatility. It filters out volatility increases due to a price increase, a case otherwise favoured by investors. The formula of the Sortino ratio is the quotient of the return premium and the negative standard deviation of the portfolio.

$$
\text { Sortino ratio }=\left(r_{i}-r_{f}\right) / \sigma_{d},
$$

where $r_{i}$ is the return on the asset, $r_{f}$ is the risk-free return, and $\sigma_{d}$ is the standard deviation of negative returns.

Applying the Markowitz portfolio theory and incorporating enhancements on the capital asset pricing model (CAPM) based on that theory, various models and indicators can be used for evaluative comparisons of investment opportunities in terms of risk and return optimisation. The CAPM model works well in theory, but its assumptions are prejudiced in practice, and have brought about a multitude of market anomalies. Given that in practice it is realised (ex post) returns that can be observed (Lovas et al. 2019), we work with the single-factor index model instead of the CAPM model. The single-factor index model is a regression model that measures the excess return achieved by the portfolio against the benchmark. This approach allows us to measure the performance of the green bond portfolio we have compiled against that of the market. The line fitted on the return premiums of the asset and the market using the ordinary least squares (OLS) method is the security characteristic line $(\mathrm{SCL})$, with beta slope and alpha intercept (Bodie et al. 2005). Alpha, or Jensen's alpha, quantifies the excess return on the portfolio, expressing the size of the difference between the average return on the portfolio and the return obtained with CAPM (here: index model).

$$
\alpha_{i}=E\left(r_{i}\right)-\left[r_{f}+\beta_{i} \cdot\left(E\left(r_{m}\right)-r_{f}\right)\right],
$$

where $\alpha_{i}$ is the excess return, $E\left(r_{i}\right)$ is the theoretical expected return obtained with CAPM, $\beta_{\mathrm{i}}$ is the undiversifiable market risk, and $E\left(r_{m}-r_{f}\right)\left(=E\left(r_{m}\right)-r_{f}\right)$ is the expected market risk premium. A positive value of Jensen's alpha $\left(\alpha_{i}\right)$ indicates that the fund

\footnotetext{
${ }^{5}$ Rollinger, T.N. - Hoffmann, S.T.: Sortino: A 'Sharper' Ratio. https://www.cmegroup.com/education/files/ rr-sortino-a-sharper-ratio.pdf. Downloaded: 5 June 2019.
} 
manager achieved a higher return than the reference index, i.e. that active portfolio management was successful. In the regression equation, alpha was tested using a t-test, in which $\mathrm{H}_{0}: \alpha=0$. If the null hypothesis can be rejected, i.e. $\alpha$ is not equal to zero, then active portfolio management has added value. $\beta_{i}$ explains the movement of the market portfolio in alignment with the return premium.

The indicators are first calculated over the whole period, then broken down by years, in order to observe the evolution of the risk-adjusted returns over time. By reference to Ibikunle - Steffen (2017), we expect that green bond funds will show a similar increasing trend to that seen with green equity funds due to the spread of sustainable investments.

\section{Measuring the performance of green bond funds}

We first present the average annual returns and volatility of the 11 green bond funds and the 3 reference indices to give an overview of the basic characteristics of the green bond funds included in the study. We calculated annualised logarithmic returns from daily price data for the period concerned, adjusted for the average number of trading days (250) for the purposes of annualising daily returns and standard deviation. For the purpose of determining the return premium, we considered the return on the 3-month U.S. Treasury Bill as a risk-free return.

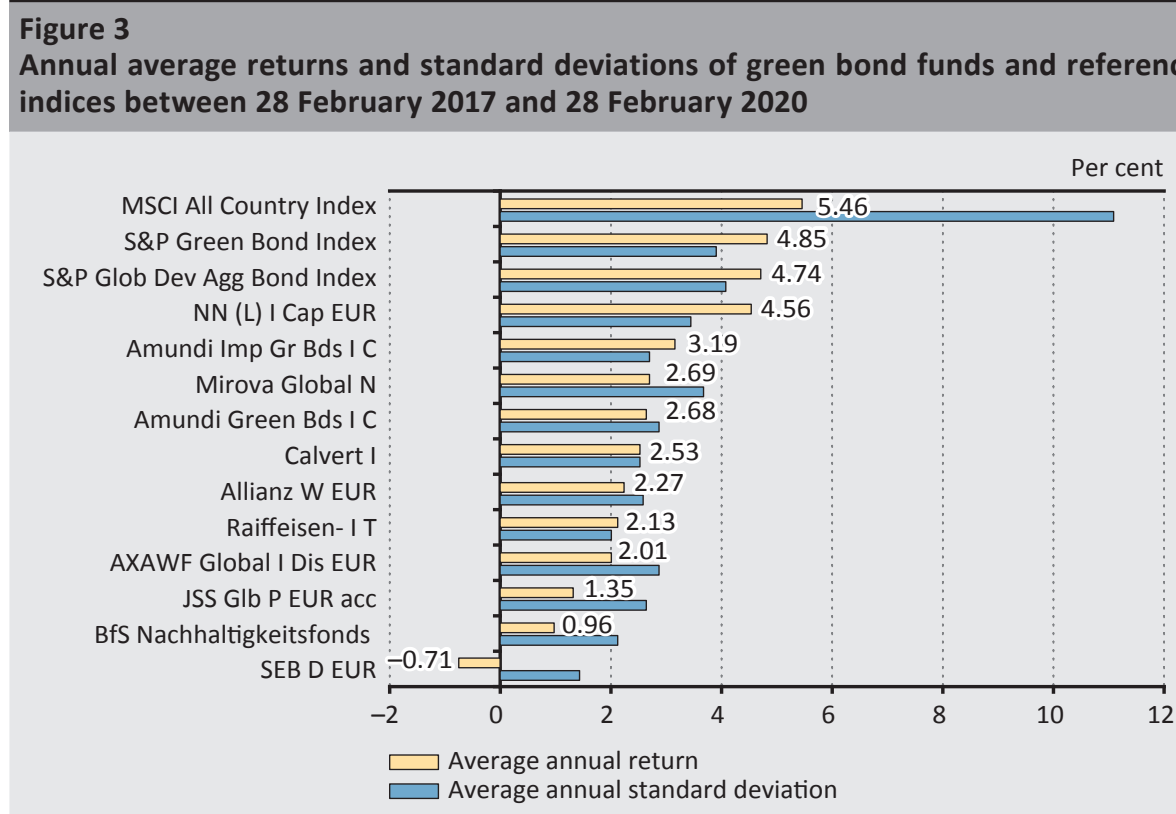

Note: The values in the figure indicate annualised returns. 
Ten of the 11 green bond funds achieved positive returns, but the return of the green bond funds was lower than that of all benchmark portfolios examined, and therefore none was able to beat the market compared to any benchmark index. The average return on the funds was 2.15 per cent, exceeding only the risk-free return (2 per cent), but falling far short of the benchmark indeces returns of around 4-5 per cent. Of the green bond funds, the NN (L) fund, with the largest asset value, excelled in performance (4.56 per cent), but even that was only sufficient to approximate the lowest-return reference index (4.74 per cent). With the funds examined, lower returns tended to be accompanied by lower risk. The results show that while green bond funds are not more profitable investments, they are less risky than market portfolios (Figure 3). Other research has also found sustainable investments to be less risky than other portfolios (Taghizadeh-Hesary et al. 2021).

As regards the evolution of standard deviations, it is not surprising that the $\mathrm{MSCl}$ All Country World Index has the highest standard deviation, which is explained by the fact that equities are riskier assets than bonds. Of the indices, the performance of the S\&P Green Bond Index and the S\&P Bond Index (the index of the conventional bond portfolio) are nearly identical in terms of both risk and return. It is noted that the green bond fund with the highest return carries only the second highest risk; however, further conclusions about the relationship between returns and standard deviations should only be drawn after calculating the risk-adjusted ratios.

\subsection{Risk-adjusted ratios}

The order of green bonds and benchmarks obtained on the basis of the annualised returns presented above can be disputed, given that portfolio managers achieved their returns by undertaking different risks. Risk-adjusted ratios are more appropriate for a correct assessment of performances. In this study, we present the performances obtained on the basis of the Sharpe ratio and its two enhanced versions, the Sortino ratio and the $\mathrm{M}^{2}$ ratio.

While the three benchmark indices performed best in terms of returns, the highest Sharpe ratio was achieved by the green benchmark index and a green bond fund, the NN (L) fund. The equity market index was also outperformed by the risk-adjusted ratios of two green bond funds. The Sharpe ratios calculated for green bond funds are positive with the exception of three funds, which means that most green bond funds outperformed the risk-free return. The average performance indicator of green bond funds is 0.07 and 0.36 with negative values excluded, coming in just ahead of the equity market index (Figure 4). 
The NN (L) fund was the only green bond fund with a higher performance than the green and conventional market indices in the period under review. Although the two Amundi funds came in behind the two mentioned indices, they outperformed the equity index. Thus, compared to the market, only a quarter of the funds proved to be superior investments that were able to achieve a higher return per unit of risk. The results also show that it is not appropriate to infer the performance from the evolution of the return alone, because, for example, the Mirova Global N Fund closed the period under review with a higher return than the Amundi Imp Fund (Figure 3 ), but it also took a much higher risk in exchange, and thus the Amundi Imp Fund, as reflected in the Sharpe ratio ranking, performed better in terms of return per unit of risk. The lowest-return green funds also rank the lowest in terms of the Sharpe ratio, as they failed to generate higher returns than the risk-free rate (Figure 4).

\section{Figure 4}

Ranking of green bond funds by Sharpe ratio, with Sortino ratios

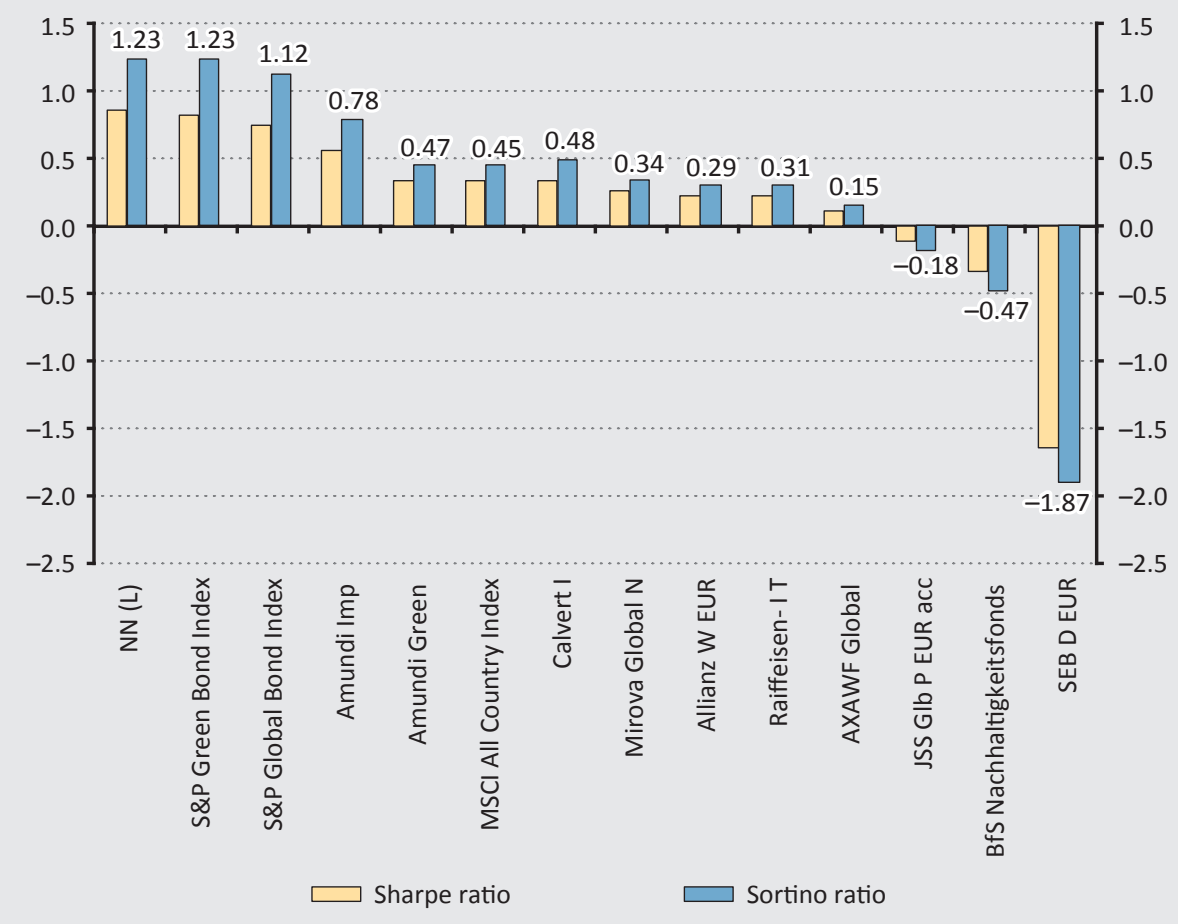

Note: The values in the figure are those of the Sortino ratio. 
The Sortino ratio is an enhanced version of the Sharpe ratio, which is more sophisticated in its treatment of price movements, because rather than penalising price increases, it only incorporates the risk of their decline. The results of the Sortino ratio only changed the order by the Sharpe ratio for two funds. Importantly, another fund, the Calvert I Fund, also beats the stock market benchmark, whereby 4 of the 11 green bond funds prove to be good investments under market conditions of the analysed period (Figure 4). All portfolios with positive Sharpe ratios also had higher Sortino ratios, i.e. there were more positive outliers than negative ones. Accordingly, we assume a return distribution with a slight stretch to the left and skewed to the right, which is also confirmed by the descriptive statistical function run on the returns, where the skewness indicator is negative, averages are lower than the median, which is in turn lower than the mode. Therefore, the returns are asymmetrical, as their distribution is not normal. Consequently, the Sortino ratio provides a more accurate result for the performance of the funds.

Looking at the return on each green bond fund separately by year, an increasing trend is seen in their performance. The observed return change warrants an examination of the risk-adjusted return ratios, broken down by period. In the first two periods considered in the study, the Sortino ratios of the funds were negative, but in the third year, i.e. from the beginning of March 2019 to the end of February 2020, seven funds outperformed all three benchmark indices and three out of four funds also outperformed two benchmark indices (Table 3). All green funds, except the SEB D EUR green bond with a negative Sortino ratio, thus outperformed the reference indices in year 3 of the period under review. Our result is consistent with the conclusion of Chen - Chang (2012) and Ibikunle - Steffen (2017) that by moving the time window forward, the green funds perform better and the green premium disappears. 


\begin{tabular}{|c|c|c|c|}
\hline \multicolumn{4}{|l|}{ Table 3} \\
\hline \multirow[b]{2}{*}{ Green bond funds } & \multicolumn{3}{|c|}{ Sortino ratios for the periods } \\
\hline & $\begin{array}{c}01.03 .2017- \\
28.02 .2018\end{array}$ & $\begin{array}{c}01.03 .2018- \\
28.02 .2019\end{array}$ & $\begin{array}{c}01.03 .2019- \\
28.02 .2020\end{array}$ \\
\hline Allianz W EUR & -1.14 & -0.98 & 2.77 \\
\hline Amundi Green Bds I C & -1.09 & -1.14 & 3.32 \\
\hline Amundi Imp Gr Bds I C & -0.95 & -0.69 & 3.32 \\
\hline AXAWF Global I Dis EUR & -1.50 & -1.27 & 2.53 \\
\hline BfS Nachhaltigkeitsfonds & -1.31 & -2.21 & 2.21 \\
\hline Calvert I & -1.85 & -0.81 & 3.43 \\
\hline JSS GIb P EUR acc & -2.06 & -1.99 & 3.33 \\
\hline Mirova Global N & -0.82 & -0.65 & 2.48 \\
\hline NN (L) I Cap EUR & 0.04 & 0.24 & 3.16 \\
\hline Raiffeisen- I T & -1.80 & -1.02 & 3.00 \\
\hline SEB D EUR & -2.50 & -3.87 & 0.68 \\
\hline MSCI All Country Index & 2.78 & -0.56 & 0.02 \\
\hline S\&P Global Dev Agg Bond Index & 2.01 & -1.31 & 2.69 \\
\hline S\&P Green Bond Index & 3.20 & -1.43 & 2.06 \\
\hline
\end{tabular}

Another enhanced indicator of the Sharpe ratio is the $\mathrm{M}^{2}$ ratio, which eliminates the lack of actual numerical comparability of the ratio (Table 3). The Sharpe ratio only ranks the funds according to their risk-adjusted performance, whereas the $\mathrm{M}^{2}$ ratio adjusts the risk of the portfolio to its market risk and gives the difference between the theoretical return on the portfolio so constructed and the return on the benchmark. It shows how much the given fund performed better or worse than the market. In this study, we infer the extent of the green premium from the evolution of the ratio.

We note that funds with negative Sharpe ratios are not applicable here and would distort the results; disregarding them (JSS Glb P, BfS Nachhaltigkeitsfonds, and SEB D EUR) produces a green premium varying between +0.2 and -1.75 basis points (Table 4). There is therefore no green premium compared to the equity index, and the returns on the green bond funds were an average 0.2 per cent higher. According to our calculations, green bond funds fell short of bond and green bond indices by about 1.58-1.75 per cent on average, which means that green bond funds pay a green premium of an average of 1.6 basis points, which is consistent with the measured values reported in the literature (MacAskill et al. 2021; Harrison 2019; Gianfrate - Peri 2019). 
Table 4

Evolution of the $\mathrm{M}^{2}$ indicators in relation to all three market (benchmark) indices

\begin{tabular}{l|ccc|} 
& $\begin{array}{c}\mathbf{M}^{2} \text {-ratio (\%) } \\
\text { (stock index) }\end{array}$ & $\begin{array}{c}\mathbf{M}^{2} \text {-ratio (\%) } \\
\text { (bond index) }\end{array}$ & $\begin{array}{c}\mathbf{M}^{2} \text {-ratio (\%) } \\
\text { (green bond index) }\end{array}$ \\
\hline NN (L) & 5.49 & 0.38 & 0.11 \\
S\&P Green Bond Index & 5.17 & 0.26 & - \\
S\&P Global Bond Index & 4.47 & - & -0.25 \\
Amundi Imp & 2.29 & -0.80 & -1.02 \\
Amundi Green & -0.02 & -1.64 & -1.82 \\
MSCI All Country Index & - & -1.65 & -1.82 \\
Calvert I & -0.10 & -1.69 & -1.86 \\
Mirova Global N & -0.76 & -1.93 & -2.09 \\
Allianz W EUR & -1.36 & -2.15 & -2.30 \\
Raiffeisen- I T & -1.42 & -2.17 & -2.33 \\
AXAWF Global & -2.55 & -2.59 & -2.72 \\
\hline Average green premium & 0.20 & -1.58 & -1.75 \\
\hline
\end{tabular}

The values of the Sharpe ratio and the Sortino ratio depend only on the average return, the risk-free return and the overall or downside risk. The ratios were not affected by the choice of the benchmark index, regardless of whether their performance was compared to the conventional or green indices. However, as the benchmark index is also used in the calculation of the $\mathrm{M}^{2}$ index, we have shown the results for all three indices, although it can be seen from our subsequent calculation that only one benchmark index correlates with the return on green bond funds.

Taking into account the risk-adjusted ratios alone is not sufficient to determine how the funds performed relative to one another; accordingly, in the following we present the results calculated using the univariate index model based on the CAPM model. Before that, we need to take a look at the benchmarks we have chosen. The values of alpha and beta, which measure the portfolio manager's ability to select and manage funds, and the movement of funds with the market, are sensitive to the benchmarks chosen. This raises the question of which benchmark to choose.

We found a slight negative correlation between green bond funds and the global equity market, which varies between -0.2 and 0 ; accordingly, we used a t-test to confirm that the values of the two returns are independent of each other. However, there is already a stronger, positive significant correlation between funds and bond indices. Surprisingly, we found the global bond index to correlate better with green bond portfolios than the green index. This may be due to the fact that while the former may contain green securities, the latter excludes conventional bonds, whereby its composition is less similar to that of the funds. In their analysis of ethical investment funds, Bauer et al. (2005) also concluded that explanatory power 
of ethical indices was very weak. Drawing on the results from the correlation study, the return premium of the funds is compared to the global bond index, as the correlation calculation shows that the $\mathrm{MSCl}$ All Country World Index is less powerful in explaining their extent.

Table 5 shows the results of the regression equation run with the S\&P Global Bond Index, where the dependent variable is the return premium of the index and the independent variable comprises the premiums of the funds above the risk-free return. Jensen's alpha basically gives the excess return above the expected return according to the CAPM model, but due to the latter's practical difficulties mentioned earlier, we use the index model to measure the return premiums.

\begin{tabular}{|c|c|c|c|}
\hline \multicolumn{4}{|c|}{$\begin{array}{l}\text { Table } 5 \\
\text { Parameters of the univariate index model with the bond market index }\end{array}$} \\
\hline Green bond funds & Alfa (\%) & Beta & $\mathbf{R}^{2}$ \\
\hline Allianz W EUR & 0.001 & $0.16^{*}$ & 0.06 \\
\hline Amundi Green Bds I C & 0.0026 & $0.37^{*}$ & 0.28 \\
\hline Amundi Imp Gr Bds I C & 0.0045 & $0.38^{*}$ & 0.33 \\
\hline AXAWF Global I Dis EUR & 0.0003 & $0.35^{*}$ & 0.25 \\
\hline BfS Nachhaltigkeitsfonds & -0.0011 & $0.19 *$ & 0.13 \\
\hline Calvert I & 0.0016 & $0.40 *$ & 0.42 \\
\hline JSS GIb P EUR & -0.0022 & $0.34^{*}$ & 0.28 \\
\hline Mirova Global N & 0.0022 & $0.40^{*}$ & 0.20 \\
\hline NN (L) I Cap EUR & 0.0099 & $0.39 *$ & 0.21 \\
\hline Raiffeisen- I T & 0.0058 & $0.06^{*}$ & 0.01 \\
\hline SEB D EUR & $-0.0068^{*}$ & $0.37^{*}$ & 0.13 \\
\hline Note: ${ }^{*} p<0.05$ & & & \\
\hline
\end{tabular}

Regarding the performance of the green bond funds, it may be asserted that the eight funds with positive alphas out of the 11 funds managed actively outperformed the global bond index benchmark representing the market. The results of the abnormal yields adjusted for the risk obtained with Jensen's alpha are consistent with our previous calculations, according to which the BfS Nachhaltigkeitsfonds, JSS GIb P EUR and SEB D EUR funds produced negative returns, negative Sharpe ratios and also negative Sortino ratios. However, when the $p$ values are measured at a significance level of 5 per cent, we can reject the null hypothesis only for the SEB fund, which means that a significant difference from the bond index in terms of performance is found for one of the funds, the poorest performer; however, due to the low value of the determination coefficient, no far-reaching conclusions can be drawn regarding the green premium. 
In our analysis, it can be seen from the significant betas that the benchmark index sufficiently explains the performance of the funds. We use the t-test of the betas to explain the market sensitivity of an asset, with the beta indicating the change in the return on a given asset triggered by the change in the return on the benchmark index. The average of the betas is 0.21 , implying movements that are only marginally aligned with the market, and therefore less risky assets. The beta of the Calvert I fund is the highest at 0.42 , which is also the fund with the highest reading for the determination coefficient, meaning that the variance of the return premium of the Calvert I fund is explained by the global bond index at 42 per cent.

Overall, active fund management had no effect on the evolution of the returns on the green bond funds, which is equivalent to unsuccessful fund manager operations for failure to use ability to beat the market. Our results confirm those of Fama French (2020) on actively managed U.S. equity funds, which underperformed the market in the long run even after adjustments for cost; indeed, the alphas obtained for actively managed funds were essentially negative.

\section{Summary}

A green revolution is taking place in the capital markets. Sustainable securities for achieving climate objectives appear to be a popular investment opportunity, but surprisingly, the key to their spread was not necessarily higher returns. From the empirical literature on green bonds, we showed that investors are willing to forego a part of their returns for the benefit of issuers, and to participate in climate finance, supporting the achievement of sustainable goals by paying a green premium. The green premium is a negative return compared to another conventional instrument with similar characteristics, and as such it can be considered as a kind of return sacrifice on the part of the investor, used by the issuer to finance the costs incurred to have the product green rated. However, our research also shows that the "greening" asset allocation by investors is not destined to be loss-making, but can be a profitable strategy for them even in the medium term.

We formulated two hypotheses. The first hypothesis was accepted, as the underperformance of the green bond funds compared to the benchmarks could be seen from the evolution of the returns and the risk-adjusted ratios. The average value of the $\mathrm{M}^{2}$ ratio confirmed the existence of a green premium for two benchmarks, and green bonds performed only marginally better than the equity index. However, due to the low explanatory power and insignificant results, we could not draw valid conclusions for the green premium from the CAPM-based regression model. We also accepted our other hypothesis on the grounds of the outstanding performance shown throughout the period by a single green bond 
fund, the NN (L) fund, confirming the possibility to invest in a profitable green bond portfolio without a green premium.

Our research confirms the link that initially the choice of investors to invest in green bonds "only" had reputational value, but over time, with the continuation of the trend that emerged from our data, the green premium disappears, and green bonds are expected to have better performance and higher returns. Looking at the entire period, we confirmed the existence of green premiums for the majority of the funds in the portfolio of 11 green bonds, but over the years the green premium became less frequent and smaller. In this way, we were able to capture the green premium as priced in by the market, another view that is widely held in the literature. The annual analysis of the Sortino ratios showed green bonds to perform increasingly better, and the ability of some to outperform the benchmark indices.

Our findings highlight the role and importance of strengthening environmental preferences among bond market participants. The capitalisation of ecofriendly investor preferences can be an important catalyst for avoiding and mitigating the "dangerous" effects of climate change. Despite the poor performance of green bond funds in the overall sample, we have seen that over time they may become profitable investments as green premiums disappear, but we believe that this will only be the case if the regulatory issues around green (bond) funds are resolved.

\section{References}

Baker, M. - Bergstresser, D. - Serafeim, G. - Wurgler, J. (2018): Financing the Response to Climate Change: The Pricing and Ownership of U.S. Green Bonds. SSRN Electronic Journal. http://doi.org/10.2139/ssrn.3275327

Baranyai, E. - Banai, Á. (2020): Do climate change projections appear in mortgage characteristics? 11th Annual Financial Market Liquidity Conference, Hungary, 26-27 November.

Bauer, R. - Koedijk, C.G. - Otten, R. (2005): International evidence on ethical mutual fund performance and investment style. Journal of Banking and Finance, 29(7): 1751-1767. https://doi.org/10.1016/j.jbankfin.2004.06.035

Bodie, Z. - Kane, A. - Marcus, J.A. (2005): Befektetések (Investments). Aula Kiadó.

Boros, E. (2020): Risks of Climate Change and Credit Institution Stress Tests. Financial and Economic Review, 19(4): 107-131. http://doi.org/10.33893/FER.19.4.107131

CBI (2017): Green Bonds Highlights 2016. Climate Bonds Initiative. https://www. climatebonds.net/files/files/2016\%20GB\%20Market\%20Roundup.pdf. Downloaded: 5 May 2019. 
CBI (2020): 2019 Green Bond Market Summary. Climate Bonds Initiative. https://www. climatebonds.net/files/reports/2019_annual_highlights-final.pdf. Downloaded: 5 May 2019.

Chen, Y.S. - Chang, C.H. (2012): Enhance green purchase intentions: The roles of green perceived value, green perceived risk, and green trust. Management Decision, 50(3): 502-520. https://doi.org/10.1108/00251741211216250

Climent, F. - Soriano, P. (2011): Green and Good? The Investment Performance of US Environmental Mutual Funds. Journal of Business Ethics, 103: 275-287. https://doi. org/10.1007/s10551-011-0865-2

Deschryver, P. - de Mariz, F. (2020): What Future for the Green Bond Market? How Can Policymakers, Companies, and Investors Unlock the Potential of the Green Bond Market? Journal of Risk Financial Management, 13(3): 61. https://doi.org/10.3390/jrfm13030061

Ehlers, T. - Packer, F. (2017): Green Bond Finance and Certification. BIS Quarterly Review, September: 89-104. https://www.bis.org/publ/qtrpdf/r_qt1709h.htm. Downloaded: 5 May 2019.

Fama, E.F. - French, K.R. (2010): Luck Versus Skill in the Cross Selection of Mutual Fund Returns. The Journal of Finance, 65(5): 1915-1947. https://doi.org/10.1111/j.15406261.2010.01598.x

Filkova, M. - Boulle, B. - Frandon-Martinez, C. - Giorgi, A. - Giuliani, D. - Meng, A. - Rado, G. (2018): Bonds and Climate Change: The State of the Market 2018. https://www. climatebonds.net/files/reports/cbi_sotm_2018_final_01k-web.pdf. Downloaded: 5 May 2019.

Fogarassy, Cs. - Neubauer, É. - Mansur, H. - Tangl, A. - Oláh, J. - Popp, J. (2018): The main transition management issues and the effects of environmental accounting on financial performance - with focus on cement industry. Administratie si Management Public (31), pp. 52-66. https://www.ceeol.com/search/article-detail?id=718218. Downloaded: 8 February 2021.

Forsbacka, K. - Vulturius, G. (2019): A Legal Analysis of Terms and Conditions for Green Bonds. Europarättslig Tidskrift 3: 379-442. https://www.stockholmsustainablefinance. com/wp-content/uploads/2018/06/Forsbacka_Vulturius_2019.pdf. Downloaded: 5 June 2021.

Gianfrate, G. - Peri, M. (2019): The green advantage: Exploring the convenience of issuing green bonds. Journal of Cleaner Production, 219: 127-135. https://doi.org/10.1016/j. jclepro.2019.02.022 
Gyura, G. (2020): Az addicionalitás vizsgálata a zöld kötvények kapcsán (An examination of additionality in relation to green bonds). PhD thesis, University of Pécs. https://pea.lib.pte. hu/bitstream/handle/pea/23690/gyura-gabor-phd-2020. pdf?sequence=1\&isAllowed=y. Downloaded: 8 February 2021.

Hachenberg, G. - Schiereck, D. (2018): Are green bonds priced differently from conventional bonds? Journal of Asset Management, 19(6): 383-423. https://doi.org/10.1057/s41260018-0088-5

Harrison, S. (2019): Green Bond pricing in the primary market: January - June 2019. https:// www.climatebonds.net/files/reports/cbi_gb_pricing_h1_2019_final.pdf. Downloaded: 5 January 2020.

Hyun, S. - Park, D. - Tian, S. (2018): The Price of Going Green: The Role of Greenness in Green Bond Markets. http://www.iksa.or.kr/resource/global/hak/2018-1-1.pdf. Downloaded: 5 January 2020.

IBA (2021): Green Bond Principles and the EU framework for green finance. International Bar Association. https://www.ibanet.org/article/f43b78f6-59d7-4b29-a332-e10ccc9ffobe\#_ ftnref2. Downloaded: 25 April 2021.

Ibikunle, G. - Steffen, T. (2017): European Green Mutual Fund Performance: A Comparative Analysis with their Conventional and Black Peers. Journal of Business Ethics, 145(2): 337355. https://doi.org/10.1007/s10551-015-2850-7

ICMA (2019): Green Bond Principles Voluntary Process Guidelines for Issuing Green Bonds. International Capital Market Association. https://www.icmagroup.org/assets/documents/ Regulatory/Green-Bonds/June-2018/Green-Bond-Principles---June-2018- 140618-WEB. pdf. Downloaded: 5 September 2020.

Jókuthy, L. (2020): Zöld kötvények. Befektetés a jövő generációjának (Green bonds. Investing for the next generation). Special article, Magyar Nemzeti Bank. https://www.mnb.hu/ letoltes/jokuthy-laura-zold-kotvenyek-befektetes-a-jovo-generaciojanak.pdf. Downloaded: 5 February 2021

Karpf, A. - Mandel, A. (2018): The changing value of the 'green' label on the US municipal bond market. Nature Climate Change, 8(2): 161-165. https://doi.org/10.1038/s41558017-0062-0

Kidd, D. (2015): Indexes Sprout Up as Green Bonds Take Root. Investment Risk and Performance, 2015(1). https://deborahkidd.com/wp-content/uploads/Indexes-SproutUp-as-Green-Bonds-Take-Root-1.pdf. Downloaded: 2 February 2019. 
Kolozsi, P. P. (2019): Piaci összeomlással fenyeget a klímaváltozás? (Is climate change threatening with collapse?) Economania. https://economaniablog.hu/2019/12/17/piaciosszeomlassal-fenyeget-a-klimavaltozas/. Downloaded: 25 April 2021.

Lovas, A. - Berlinger, E. - Dömötör, B. - Keresztúri, J.L. - Ölvedi, T. - Petróczy, D.G. - Pollák, Z. (2019): Pénzügyi számítások - Bevezetés a pénzügyi termékek értékelésébe (Financial calculations - Introduction to the valuation of financial products). http://unipub.lib.unicorvinus.hu/4465/1/PenzugyiSzamitasokKonyv_201912.pdf. Downloaded: 5 February 2020

MacAskill, S. - Roca, E. - Liu, B. - Stewart, R.A. - Sahin, O. (2021): Is there a green premium in the green bond market? Systematic literature review revealing premium determinants. Journal of Cleaner Production, 280(2): 124491. https://doi.org/10.1016/j. jclepro.2020.124491

MNB (2019): Green finance in Hungary. Consultation document, Magyar Nemzeti Bank. https://www.mnb.hu/letoltes/green-finance-in-hungary-consultation-paper.pdf. Downloaded: 5 January 2020.

Mihálovits, Zs. - Tapaszti, A. (2018): Zöldkötvény, a fenntartható fejlödést támogató pénzügyi instrumentum (Green Bond, the Financial Instrument that Supports Sustainable Development). Pénzügyi Szemle (Public Finance Quarterly), 2018(3): 312-327.

Nanayakkara, M. - Colombage, S. (2019): Do investors in Green Bond market pay a premium? Global evidence. Applied Economics, (51)40: 4425-4437. https://doi.org/10.1080/0003 6846.2019.1591611

Németh-Durkó, E. (2019): Környezet és pénzügyek (Environment and finance). Discussion paper, Corvinus University of Budapest, Department of Investment and Corporate Finance, Budapest. http://unipub.lib.uni-corvinus.hu/4294/. Downloaded: 1 November 2019.

OECD (2017): Investing in Climate, Investing in Growth. OECD Publishing, Paris. http://doi. org/10.1787/9789264273528-en

Partridge, C. - Medda, F.R. (2020): The evolution of pricing performance of green municipal bonds. Journal of Sustainable Finance and Investments, 10(1): 44-64. https://doi.org/10 $.1080 / 20430795.2019 .1661187$

Pham, L. (2016): Is it risky to go green? A volatility analysis of the green bond market. Journal of Sustainable Finance \& Investment, 6(4): 1-29. http://doi.org/10.1080/20430795.201 6.1237244

Rácz, D.A. (2019): Abszolút hozamú befektetési alapok teljesítményének értékelése a teljesítménymanipulálás kimutatása (Performance evaluation of absolute return funds - Detecting performance manipulation). Közgazdasági Szemle (Economic Review), 66(7-8): 824-846. https://doi.org/10.18414/KSZ.2019.7-8.824 
Reichelt, H. (2010). The euromoney environmental finance handbook - Green bonds: a model to mobilise private capital to fund climate change mitigation and adaptation projects. https://documents1.worldbank.org/curated/en/680921507013408005/pdf/120168-BRIPUBLIC-euromoney-handbook-2010-green-bonds.pdf. Downloaded: 2 May 2019.

Sági, J. (2020): Zöldkötvények kibocsátásának egyes kérdései, a környezeti célokkal összefüggésben (Certain Aspects of Green Bond Issuances in Relation to Environmental Goals). Polgári Szemle (Civic Review Journal of Economic and Social Sciences), 16(46): 270-278. https://doi.org/10.24307/psz.2020.1019

Stempler, B. (2021): ESG Investing: The Use of ESG Ratings in a Smart Beta Strategy. Financial and Economic Review, 20(2): 91-116. http://doi.org/10.33893/FER.20.2.91116

Sartzetakis, E.S. (2020): Green bonds as an instrument to finance low carbon transition. Economic Change and Restructuring, 54: 755-779. https://doi.org/10.1007/s10644-02009266-9

Shislov, I. - Morel, R. - Cochran, I. (2016): Beyond transparency: unlocking the full potential of green bonds. Institute for Climate Economics. https://www.i4ce.org/wp-core/wp-content/ uploads/2016/06/I4CE_Green_Bonds-1.pdf. Downloaded: 2 February 2019.

Timár, B. (2021): How Does the Market Price Responsible and Sustainable Investments? Financial and Economic Review, 20(2): 117-147. http://doi.org/10.33893/FER.20.2.117147

Taghizadeh-Hesary, F. - Yoshino, N. - Phoumin, H. (2021): Analyzing the Characteristics of Green Bond Markets to Facilitate Green Finance in the Post-COVID-19 World. Sustainability, 13(10): 5719. https://doi.org/10.3390/su13105719

Tang, D.Y. - Zhang, Y. (2018): Do shareholders benefit from green bonds? Journal of Corporate Finance, 61(C). https://doi.org/10.1016/j.jcorpfin.2018.12.001

Tuhkanen, H. - Vulturius, G. (2020): Are green bonds funding the transition? Investigating the link between companies' climate targets and green debt financing. Journal of Sustainable Finance \& Investment. https://doi.org/10.1080/20430795.2020.1857634

Zerbib, O.D. (2019): The effect of pro-environmental preferences on bond prices: Evidence from green bonds. Journal of Banking \& Finance, 98(January): 39-60. https://doi. org/10.1016/j.jbankfin.2018.10.012 